\title{
Physiological Quality of Hybrids and Creole Maize Seeds
}

\section{Qualidade Fisológica de Sementes de Milho Híbrido e Crioulo}

\author{
Helis Maria Salomão; Silvia Rahe Pereira*b; Andreia Suchoronczek ${ }^{c}$; Adriano Suchoronczek ${ }^{\mathrm{d}}$; Larissa Leite Momolia \\ Sayonara Salvatti Müller ${ }^{\mathrm{a}}$; Aline Ferreira Coelho ${ }^{\mathrm{b}}$; Adriana Paula D’Agostini Contreiras Rodrigues ${ }^{\mathrm{a}}$ \\ ${ }^{a}$ Universidade Tecnológica Federal do Paraná, Campus Pato Branco. PR, Brasil. \\ bUniversidade Anhanguera UNIDERP, Programa de Pós-Graduação Stricto Sensu em Produção e Gestão Agroindustrial. MS, Brasil. \\ 'Universidade Estadual do Centro-Oeste, Programa de Pós-Graduação Stricto Sensu em Biologia. PR, Brasil. \\ ¿Universidade Tecnológica Federal do Paraná, Campus Pato Branco, Programa de Pós-Graduação Stricto Sensu em Agronomia. PR, Brasil. \\ *E-mail: silviarahe@gmail.com
}

\begin{abstract}
The aim of this study was to evaluate the physiological quality of hybrid maize seeds (within the validity period and expired seeds) and of a Creole variety within the validity period. The study was performed using the hybrids C1 BM3063 PRO 2 (valid until 12/2018) and C1 SYN8A98 (valid until 03/2017 - expired one year ago) and a Creole maize (freshly harvested, collected at Pato Branco city, Paraná State, Brazil). Seed germination, germination speed index, germination speed, cold test, length and fresh and dried matter of shoot and root system were evaluated in a laboratory experiment. In the field we evaluated emergency, emergency speed index, emergency speed, length and fresh and dried matter of aerial part. Creole cultivar had the worse performance in all the variables tested. Expired hybrid (SYN8A98) presented similar development to the hybrid within the validity period (BM3063) in practically all the evaluated parameters. SYN 8A98 hybrid can be sown without risks of reduced productivity, provided that cold periods during field establishment are avoided. Creole variety in question did not perform satisfactorily and could not be used as seed.
\end{abstract}

Keywords: Seeds Validity Period. Open Pollinated Variety. Viability. Production Costs. Seeds Reuse.

\section{Resumo}

O objetivo deste estudo foi avaliar a qualidade fisiológica de sementes de milho híbrido (dentro do periodo de validade e sementes expiradas) e de uma variedade crioula dentro do periodo de validade. O estudo foi realizado utilizando os híbridos C1 BM3063 PRO 2 (válido até 12/2018) e C1 SYN8A98 (válido até 03/2017 - expirou há um ano) e um milho crioulo (recém-colhido, coletado na cidade de Pato Branco, Paraná, Brasil). Foram avaliados, em experimento laboratorial, a germinação de sementes, o índice de velocidade de germinação, a velocidade de germinação, o teste de frio, o comprimento e matéria fresca e seca da parte aérea e sistema radicular. No campo foram avaliados emergência, indice de velocidade de emergência, velocidade de emergência, comprimento e matéria fresca e seca da parte aérea. A cultivar crioula teve o pior desempenho em todas as variáveis testadas. O híbrido expirado (SYN 8A98) apresentou desenvolvimento similar ao híbrido dentro do periodo de validade (BM3063) em praticamente todos os parâmetros avaliados. O híbrido SYN 8 A98 pode ser semeado sem riscos de produtividade reduzida, desde que sejam evitados períodos frios durante o estabelecimento em campo. A variedade crioula em questão não teve desempenho satisfatório e não pôde ser usada como semente.

Palavras-chave: Periodo de Validade das Sementes. Variedade de Polinização Aberta. Viabilidade. Custos de Produção. Reutilização de Sementes.

\section{Introduction}

Maize (Zea mays L.) is one of the most cultivated cereals in the world, belongs to the family Poaceae, originating in Central America, more specifically from Mexico (GALVÃO; BORÉM; PIMENTEL, 2017). USA and China are the largest producers of the grain, accounting for 37 and $21 \%$ of the world total produced, respectively (CONAB, 2018). Brazil is the third largest producer in the world (with 82 million tons produced) and the second largest exporter of the grain (ANTUNES, 2019).

Brazilian maize production is mainly destined to agroindustrial system, where grain is processed. Due to its high nutritional quality, it is one of the main sources of human and animal feeding (such as cattle, pigs and poultry) and is used for the biofuels production in the technological industries
(CRUZ, 2011; OLIVEIRA JÚNIOR et al., 2006; COUTO et al., 2017; ROSSETO et al., 2017; GOMES et al., 2018). In addition, maize is used in silage production, where the plant still in the reproductive stage is crushed, compacted and passes through anaerobic fermentation process (GALVÃO; BORÉM; PIMENTEL, 2017).

In the last 40 years, traditional maize varieties have been replaced by hybrid cultivars, with higher productive potential and greater requirements in fertilization, irrigation and pesticides to express their potential productive (EMYGDIO et al., 2008). Open pollinated varieties are essential for maize breeding programs. Many of these materials are kept in their origin center, germplasm banks or cultivated by small producers. Small producers usually have a lower level of technology and use a smaller amount of inputs, obtaining 
better economic return with native varieties (PAULUS; MACHADO NETO, 2001). However, in order to obtain high yields in maize crop, attention should be paid to factors such as the use of seeds with high physiological and sanitary quality, adapted to the edaphoclimatic conditions of the planting region (MARCOS FILHO, 2015; PIZÁ et al., 2018).

Seed quality is defined as the sum of four basic characteristics, being genetic, physiological, physical and sanitary potential (FRANÇA NETO, 2009). Among the characteristics most studied in germplasm banks and seed industry, we highlight physiological potential (KAPPES et al., 2012; CARDOSO et al., 2012). This congregate information about germination (viability) and seed vigor (MARCOS FILHO, 2015). Germination can be defined as the reactivation of embryo growth, which results in seed cover rupture and seedling emergence (COPELAND; MCDONALD, 1995). Already, vigor is defined as the properties set capable of determining rapid and uniform germination in the development of normal seedlings under different environmental conditions (AOSA, 1983; FRANÇA NETO et al., 2010).

It is important to emphasize that seeds vigor loss is related to degenerative changes of biochemical, physiological and physical origin, reducing germination and triggering a greater sensitivity to environmental conditions (DELOUCHE; BASKIN, 1973). In this way, seed physiological quality is one of the most important characteristics to be considered in crop implementation (GRABE, 1976; CARVALHO, 1986), since its evaluation is the main component of quality control. In this way, information about seed physiological quality helps to solve problems during the production process, besides estimating seed field performance (MARTINS et al., 2014).

Maintenance of seed physiological quality, which is essential for sowing must be ensured throughout storage (PACHECO et al., 1998). There are few studies that prove that, in fact, after validity period expiration of a maize seed, its vigor and germination do not allow the field sowing, questioning about the possible reuse of these materials as an alternative of costs reduction, due high seeds costs. Thus, the aim of the present study was to evaluate maize seeds physiological quality, evaluating the hybrid BM3063 and a creole variety within the validity period and the SYN8A98 hybrid, with validity period expired one year ago.

\section{Material and Methods}

The study was carried out in the Seeds Analysis Laboratory of the Federal Technological University of Paraná, Campus Pato Branco and in the field, in a property at Vitorino city in Paraná State $\left(26^{\circ} 16^{\prime} 48.2^{\prime \prime}\right.$ S and $52^{\circ} 47^{\prime} 27.9$ 'W), with a climate in transition between $\mathrm{Cfa}$ and $\mathrm{Cfb}$ (KÖPPEN; GEIGER, 1928) in March 2018.

Three maize materials (one lot for each material) were used: 1) BM3063 PRO 2 hybrid with validity up to 12/2018 industrially treated with Clotianidin (Poncho ${ }^{\circledR}, 400 \mathrm{~mL} / 100$ $\mathrm{kg}$ ) in $12 / 2017$; 2) SYN8A98 hybrid with validity period expired one year ago (March 2017), industrially treated wtih Thiamethoxam (Cruiser $350 \mathrm{FS} \AA$, $600 \mathrm{~mL} / 100 \mathrm{~kg}$ ) in March 2016 ; 3 ) creole maize seed recently harvested (30 days postharvested) in Pato Branco city, Paraná State, without seed treatment.

Seeds of the three materials (both hybrids and Creole seed) were stored under controlled humidity and temperature conditions in a cold chamber. They had a constant moisture content of $13 \%$.

The analyzes were carried out in the laboratory to assess the physiological and seed development aspects characterization. They were carried out using germitest paper as substrate, moistened with the equivalence of 2.5 times its initial weight. The seeds were incubated in Mangelsdorf germinator with a temperature of $25{ }^{\circ} \mathrm{C}$ and controlled humidity. Including experiments conducted in the field, we carried out five experiments and the following tests were performed.

\subsection{First experiment}

Germination speed index (GSI): 50 seeds were uniformly deposited on two germitest paper sheets, previously moistened and covered with another leaf and rolled. We used 8 replicates. We carried out daily evaluations up to the seventh day after the test start, counting seeds with at least $2.0 \mathrm{~mm}$ of seminal root (JUNTILA, 1976). GSI was determined according to the formula GSI $=\mathrm{G} 1 / \mathrm{T} 1+\mathrm{G} 2 / \mathrm{T} 2+\ldots+\mathrm{G} 7 / \mathrm{T} 7$, where G1 to $\mathrm{G} 7$ is equal to the sum of the seeds germinated each day; and T1 to T7 represents the time in days (NAKAGAWA, 1999).

Germination speed (GS): evaluated through the same execution and evaluations procedures cited for the GSI. The used formula $\mathrm{GS}=\mathrm{G} 1 * \mathrm{~T} 1+\mathrm{G} 2 * \mathrm{~T} 2+\ldots+\mathrm{G} 7 * \mathrm{~T} 7 / \mathrm{SN}$, where $\mathrm{G} 1$ to $\mathrm{G} 7$ represents seeds number germinated each day, T1 to T7 the time in days; and NS total seeds number sown (NAKAGAWA, 1999).

\subsection{Second experiment}

Germination $(\mathrm{G})$ : germination test were carried out through the same execution procedures mentioned for the first experiment. Evaluations were carried out at the fourth day by counting normal seedlings and at the seventh day by counting normal and anormal seedlings and dead seeds. Germination corresponds to the sum of normal seedling data at the fourth and seventh days, expressed as a percentage (BRAZIL, 2009).

\subsection{Third experiment}

Cold test (CT): this test were carried out through the same execution procedures previously mentioned, being the rollers deposited in transparent plastic bags and maintained for seven days in the refrigerator with temperature close to $4{ }^{\circ} \mathrm{C}$. After that, they were placed into germinator and the evaluations were performed four days after the test start (DIAS; BARROS, 1995). 


\subsection{Fourth Experiment}

Aerial and root part length, fresh and dry shoot and root mass: 25 seeds were deposited transversely on 2 germitest paper sheets previously moistened. The seeds were positioned to the roller upper portion and kept in the germinator for 7 days, when root and aerial length of each seedlings were measured with a ruler. Seedlings fresh mass were registered and they were placed in paper packages, for 72 hours at $60{ }^{\circ} \mathrm{C}$. After this period seedlings dry mass was registered (VIEIRA; KRZYZANOWSKI, 1999).

\subsection{Fifth experiment}

In the field, four replicates of 25 seeds were sown at 3 $\mathrm{cm}$ depth and we evaluated: emergency speed index (ESI), emergency speed (ES), emergency (E), shoot length and shoot fresh and dried mass at 7 days. For these, we performed the same methodologies previously mentioned (VIEIRA; KRZYZANOWSKI, 1999).

The results were submitted to ANOVA using SAS Studio ${ }^{\circledR}$ 3.5 software and when significant the means were compared by the Tukey test at $5 \%$ of error probability.

\section{Results and Discussion}

BM 3063 and SYN 8A98 materials obtained better performance in relation to the creole cultivar when analyzed the results of G and GSI (Table 1). According to the results, it can be inferred that expired seed physiological quality (SYN 8A98) does not differ from a seed within the validity period (BM 3063), and therefore both meet the standards for seeds commercialization, which must be higher than $85 \%$. Creole cultivar, however, did not reach the minimum required germination percentage, and cannot be used as seed (BRAZIL, 2013).

Creole cultivar, on the other hand, germinated in a shorter period of time (lower VG) compared to the out-dated cultivar (SYN 8A98), occupying BM 3063 cultivar an intermediate position (Table 1). Although we detected significant differences for VG among the evaluated materials, none took more than two days to germinate. This result can be considered as a good germination speed value, implying into a rapid emergence and establishment, allowing a shorter time exposure of seeds to soil pathogens that may negatively affect their viability, as well as reducing the competition wtih weeds (KIMATI et al, 2005; DIAS; MONDO; CICERO, 2010).
Table 1 - Germination (G), germination speed index (GSI), germination speed (GS) and cold test (CT) in maize seeds of a hybrid within the expiration date (BM 3063), an expired hybrid (SYN 8A89) and a creole cultivar recently harvested

\begin{tabular}{|c|c|c|c|c|}
\hline Materials & G\% & GSI & GD (days) & CT \% \\
\hline BM 3063 & $98.0 \mathrm{a}$ & $81.1 \mathrm{a}$ & $1.9 \mathrm{ab}$ & $90.0 \mathrm{a}$ \\
\hline SYN 8A98 & $94.0 \mathrm{a}$ & $77.0 \mathrm{a}$ & $2.0 \mathrm{~b}$ & $65.5 \mathrm{~b}$ \\
\hline Creole & $79.0 \mathrm{~b}$ & $60.50 \mathrm{~b}$ & $1.9 \mathrm{a}$ & $41.5 \mathrm{c}$ \\
\hline
\end{tabular}

Means followed by the same letter in each columns do not differ significantly $(\mathrm{p}<0.05$; Tukey test $)$.

Source: Research data

Regarding the cold test (Table 1), the material that stood out was BM 3063 hybrid, followed by the SYN 8A98 hybrid. Creole variety showed inferior development compared to others. This result allows us to assume a seedlings emergence delaying the field due to the occurrence of cold and humid days (COIMBRA et al., 2009; MARCOS FILHO, 2015), a fact commonly found in early crops sown, mainly in colder places such as in the south of Brazil (GRZYBOWSKI; VIEIRA; PANOBIANCO, 2015).

These results were proved in the field test (Table 2), where we found the same pattern observed for E, ESI and ES to those obtained in the laboratory. However, in general, performance of all variables was lower, fact that can be explained because field conditions are not ideal as the in laboratory. There was little variation in the ES, being that BM 3063 hybrid did not differ from the expired hybrid (SYN 8A98).

Table 2 - Emergence (E), emergence speed index (ESI) and emergence speed (ES) and cold test (CT) in maize seeds of a hybrid within the expiration date (BM 3063), an expired hybrid (SYN 8A89) and a creole cultivar recently

\begin{tabular}{|c|c|c|c|}
\hline Materials & E\% & ESI & ES \\
\hline BM 3063 & $94.0 \mathrm{a}$ & $81.1 \mathrm{a}$ & $2.5 \mathrm{~b}$ \\
\hline SYN 8A98 & $96.0 \mathrm{a}$ & $77.0 \mathrm{a}$ & $2.5 \mathrm{~b}$ \\
\hline Creole & $69.0 \mathrm{~b}$ & $60.5 \mathrm{~b}$ & $1.9 \mathrm{a}$ \\
\hline
\end{tabular}

Means followed by the same letter in each columns do not differ significantly $(\mathrm{p}<0.05$; Tukey test).

Source: Research data

Shoot length obtained in the laboratory differed among the evaluated materials (Table 3). Better performance was obtained by the hybrid BM 3063, SYN 8A98 presented intermediate position and worst result was found for creole cultivar. In the field (Table 4), however, shoot length of expired hybrid (SYN 8A98) did not differ from the hybrid within the validity period (BM 3063). Again, the worst performance was obtained in creole cultivar.

Table 3 - Shoot and root lenght $(\mathrm{cm})$, fresh mass $(\mathrm{g})$ and dry massa $(\mathrm{g})$ of maize seedlings, in laboratory tests of a hybrid within the expiration date (BM 3063), an expired hybrid (SYN 8A89) and a creole cultivar recently harvested

\begin{tabular}{|c|c|c|c|c|c|c|}
\hline \multirow{2}{*}{ Materiais } & \multicolumn{2}{|c|}{ Lenght (cm) } & \multicolumn{2}{c|}{ Fresh mass (g) } & \multicolumn{2}{c|}{ Dry mass (g) } \\
\cline { 2 - 7 } & Shoot & Root & Shoot & Root & Shoot & Root \\
\hline BM 3063 & $9.39 \mathrm{a}$ & $14.22 \mathrm{a}$ & $10.08 \mathrm{a}$ & $6.36 \mathrm{a}$ & $0.99 \mathrm{a}$ & $0.77 \mathrm{a}$ \\
\hline SYN 8A98 & $8.79 \mathrm{ab}$ & $13.75 \mathrm{a}$ & $8.54 \mathrm{ab}$ & $5.60 \mathrm{a}$ & $0.69 \mathrm{~b}$ & $0.65 \mathrm{a}$ \\
\hline Creole & $7.07 \mathrm{~b}$ & $13.23 \mathrm{a}$ & $7.70 \mathrm{~b}$ & $5.66 \mathrm{a}$ & $0.68 \mathrm{~b}$ & $0.62 \mathrm{a}$ \\
\hline
\end{tabular}

Means followed by the same letter in each columns do not differ significantly ( $<<0.05$; Tukey test).

Source: Research data 
Table 4 - Shoot lenght (cm), fresh mass ( $\mathrm{g}$ ) and dry massa (g) of maize seedlings, in field test of a hybrid within the expiration date (BM 3063), an expired hybrid (SYN 8A89) and a creole cultivar recently harvested. Pato Branco, PR, Brazil 2018

\begin{tabular}{|c|c|c|c|}
\hline \multirow{2}{*}{ Materiais } & Lenght & Fresh mass & Dry mass \\
\cline { 2 - 4 } & $\mathrm{cm}$ & \multicolumn{2}{|c|}{$\mathrm{g}$} \\
\hline BM 3063 & $7.11 \mathrm{a}$ & $9.25 \mathrm{a}$ & $0.92 \mathrm{a}$ \\
\hline SYN 8A98 & $7.37 \mathrm{a}$ & $9.78 \mathrm{a}$ & $0.97 \mathrm{a}$ \\
\hline Creole & $5.16 \mathrm{~b}$ & $5.92 \mathrm{~b}$ & $0.57 \mathrm{~b}$ \\
\hline
\end{tabular}

Means followed by the same letter in each columns do not differ significantly ( $<<0.05$; Tukey test).

Source: Research data

In fresh and dry mass of aerial part analysis obtained in the laboratory (Table 3 ) it was observed a better performance in BM 3063 hybrid. Creole cultivar obtained a worse performance, which did not differ from the overdue hybrid (SYN 8A98).

Root length, fresh and dry root mass obtained in the laboratory (Table 3 ) did not differ among evaluated materials, demonstrating similar root system development and, possibly, no prejudice of nutrient uptake by the plant.

The worst fresh and dry shoot mass results obtained in the field were found in Creole cultivar (Table 4), while expired hybrid (SYN 8A98) and hybrid within the validity period (BM 3063 ) presented the best performance.

Analyzing the results together, it is possible to verify that the hybrid SYN 8A98 could be sown even when expired. This cultivar showed a good performance in the most relevant parameters for a proper crop establishment and, consequently, a good productivity, not differing from the hybrid within the expiration date (BM 3063). However, special care must be taken regarding sowing season, being necessary to avoid cold periods that can delay seed emergence, since in cold test the expired hybrid had a great reduce in its germination (from $94.0 \%$ in normal conditions to $65.5 \%$ in the cold test). Under these conditions, a great failure will occur in plant stand establishment (BURRIS; NAVRATI, 1979; MUNDO, 2009) and consequently a productivity reduction.

High costs of acquiring hybrid seeds (that demands in their production a technological apparatus and complex isolation), make production costly (BOREM; MIRANDA, 2013). Seeds not used in an agricultural crop are discarded, not being used in the subsequent year because they are, theoretically, with insufficient germination and vigor to be used again as seeds (GALVÃO; BORÉM; PIMENTEL, 2017, JUNQUEIRA; MORABITO, 2008). Based on the results of this research, however, it is possible to change this view, and it is feasible to send expired maize samples to the laboratory to check their physiological parameters and, in case of a positive response, to reuse the material, reducing waste and production costs.

\section{Conclusion}

Based on our experiments, expired SYN 8A98 hybrid could be sown without risk of reduced productivity, unless cold periods during field establishment are avoided. Creole variety did not perform satisfactorily and could not be used as seed.

\section{References}

ANTUNES, J.M. Produção vegetal: Melhor época para o milho no RS e SC. Embrapa milho e sorgo. 2018. Disponível em: $<$ https:// www.embrapa.br/busca-de-noticias/-/noticia/38316857/melhorepoca-para-o-milho-no-rs-e-sc>. Acesso em: 8 abr. 2019.

AOSA - Association of Official Seed Analysts. Seed vigor-testing handbook. East Leasing: AOSA. 93p, 1983.

BOREM, A.; MIRANDA, G.V. Melhoramento de plantas. Viçosa: UFV, 2013.

BRASIL. Ministério da Agricultura e da Reforma Agrária. Regras para análise de sementes. Brasília: SNDA/DNDV/CLAV, 2009.

BRASIL. Instrução Normativa MAPA 45 de setembro de 2013. Legislação específica de sementes e mudas e normas relacionadas à área. Brasília: Ministério da Agricultura, Pecuária e Abastecimento, 2013.

BURRIS, J.S.; NAVRATRI, R.J. Relationship between laboratory cold-test methods and field emergence in maize inbreds 1. Agron. J., v.71, p.985-988, 1979. doi: 10.2134/ agronj1979.00021962007100060023x

CARDOSO, R.B. et al. Potencial fisiológico de sementes de crambe em função de embalagens e armazenamento. Pesq. Agropec. Trop., v.42, n.3, p.272-278, 2012.

CARVALHO, N.M. Vigor de sementes. In: CÍCERO, S.M.; MARCOS FILHO, J.; SILVA, W.R. Atualização em produção de sementes. Campinas: Fundação Cargill, 1986. p. 207-223.

COIMBRA, R.A. et al. Testes de vigor utilizados na avaliação da qualidade fisiológica de lotes de sementes de milho-doce $(\operatorname{sh} 2)$. Ciênc. Rural, v.39, n.9, p.2402-2408, 2009.

CONAB, Companhia Nacional de Abastecimento - Levantamento da produção de grãos: safra 2018/19. Primeiro Levantamento, v.6, n.1. 2018. Disponível em: <www.conab.gov.br>. Acesso em: 7 nov. 2018.

COPELAND, L.O.; MCDONALD, M.B. Principles of seed science and technology. New York: Chapman \& Hall. 409 p, 1995.

COUTO, C.A. et al. Desempenho de cultivares de milho destinados para produção de milho verde e silagem. J. Soc. Technol. Environ. Scie., v.6, n.1, p.232-251, 2017. doi: 10.21664/2238-8869.2017v6i1.p232-251

CRUZ, J.C. et al. Milho: o produtor pergunta, a Embrapa responde. Brasília: Embrapa: Informação Tecnológica. 2011.

DELOUCHE, J.C.; BASKIN, C.C. Accelerated aging techniques for predicting the relative storability of seed lots. Seed Scie. Technol., v.1, n.2, p.427-52, 1973.

DIAS, M.A.N.; MONDO, V.H.V.; CICERO, S.M. Vigor de sementes de milho associado à mato-competição. Rev Bras. Sementes, v. 32, n. 2 p. 93-101, 2010.

DIAS, M.C.L.L.; BARROS, A.S.R. Avaliação da qualidade de sementes de milho. Londrina: IAPAR, 1995.

EMYGDIO, B.M. et al. Fenologia e características agronômicas de variedades de milho recomendadas para o RS. Pelotas: Embrapa Clima Temperado, 2008.

FRANÇA NETO, J.B. Evolução do conceito de qualidade de sementes. Informativo ABRATES, v. 19, n. 2, p. 76-80, 2009.

FRANÇA NETO, J.B. et al. Tecnologia de produção de soja de 
alta qualidade. Informativo ABRATES, v.20, n.3, p.26-32, 2010.

GALVÃO, J.C.C.; BORÉM, A.; PIMENTEL, M.A. Milho do plantio a colheita. Pelotas: UFV, 2017.

GOMES, F.H.F. et al. Análise de crescimento do milho safrinha em diferentes épocas de aplicação de zinco. Nativa, v.6, n.6, p.557-562, 2018. doi: 10.31413/nativa.v6i6.5576

GRABE, D.F. Measurement of seed vigor. J. Seed Technol., v.1, n.2, p. $18-31,1976$.

GRZYBOWSKI, C.R.S.; VIEIRA, R.D.; PANOBIANCO, M. Testes de estresse na avaliação do vigor de sementes de milho. Rev. Ciênc. Agron., v.46, n.3, p.590-596, 2015. doi: 10.5935/18066690.20150042

JUNQUEIRA, R.A.R.; MORABITO, R. Planejamento otimizado da produção e logística de empresas produtoras de sementes de milho: um estudo de caso. Gestão Prod., v.15, p.367-380, 2008.

JUNTILA, O. Seed and embryo germination in S. vulgaris and S. reflexa as effects by temperature during seed development. Physiol. Plantarum, v.29, n.2, p.264-268, 1976. doi: 10.1111/ j.1399-3054.1973.tb03103.x

KAPPES, C. et al. Qualidade fisiológica de sementes e crescimento de plântulas de feijoeiro, em função de aplicações de paraquat em pré-colheita. Pesq. Agropec. Trop., v.42, n.1, p.9-18, 2012. doi: 10.1590/S1983-40632012000100002

KIMATI, H. et al. Manual de fitopatologia. São Paulo: Agronômica Ceres, 2005.

KÖPPEN, W.; GEIGER, R. Klimate der erde. Gotha: verlag justus perthes. 1928. Wall-map

MARCOS FILHO, J. Seed vigor testing: an overview of the past, present and future perspective. Scie. Agricola, v.72, n.4, p.363374, 2015. doi: 10.1590/0103-9016-2015-0007

MARTINS, A.B.N. et al. Analysis of seed quality: a nonstop evolving activity. African J. Agricul. Res., v.9, n.49, p. 35493554, 2014. doi: 10.5897/AJAR2014.8912

NAKAGAWA, J. Testes de vigor baseados no desempenho das plântulas. In: KRZYZANOWSKI, F.C.; VIEIRA, R.D.; FRANÇA-NETO, J.B. Vigor de sementes: conceitos e testes. Londrina: ABRATES, 1999.

OLIVEIRA JÚNIOR, L.F.G. et al. Seleção de genótipos de milho mais promissores para o consumo in natura. Ciênc. Tecnol. Aliment., v.26, n.1, p.159-165, 2006.

PACHECO, C.P.A. et al. Estimativas de parâmetros genéticos nas populações CMS-42 e CMS-43 de milho pipoca. Pesq. Agropec. Bras., v.33, n.12, p.1995-2001, 1998.

PAULUS, G.; MACHADO NETO, D.P. Produção de semente própria de milho variedade. Agroecol. Desenvolv. Rural Sustentável, v.2, n.1, p.33-34, 2001.

PIZÁ, M.C.P. et al. Effects of non-thermal plasmas on seed-borne Diaporthe/Phomopsis complex and germination parameters of soybean seeds. Innovative Food Scie. Emerging Technol., v.49, p.82-91, 2018. doi: 10.1016/j.ifset.2018.07.009

ROSSETO, R.E. et al. Panorama do etanol brasileiro. Acta Iguazu, v.6, n.5, p.13-22, 2017.

VIEIRA, R.D.; KRZYZANOWSKI, F,C. Teste de condutividade elétrica. In: KRZYZANOWSKI, F.C.; VIEIRA, R.D.; FRANÇA NETO, J.B. Vigor de sementes: conceitos e testes. Londrina: ABRATES, 1999. p.1-26. 